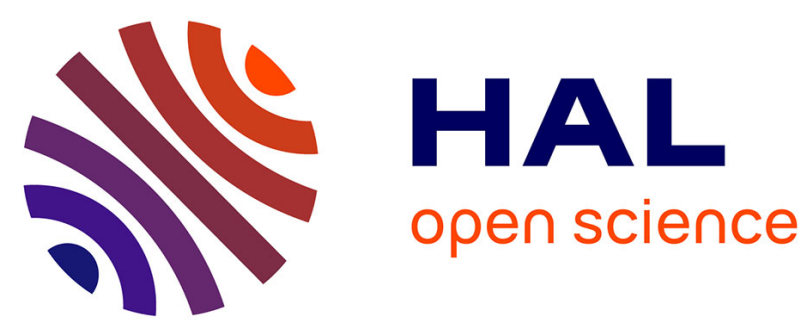

\title{
Experimental investigation of a Doubly-Excited Flux-Switching Machine for Aircraft DC Power Generation
}

Andre Nasr, Sami Hlioui, Mohamed Gabsi, Mathieu Mairie, Didier Lalevee

\section{- To cite this version:}

Andre Nasr, Sami Hlioui, Mohamed Gabsi, Mathieu Mairie, Didier Lalevee. Experimental investigation of a Doubly-Excited Flux-Switching Machine for Aircraft DC Power Generation. IEEE International Electric Machines \& Drives Conference, May 2017, Miami, Florida, United States. hal-01551422

\author{
HAL Id: hal-01551422 \\ https://hal.science/hal-01551422
}

Submitted on 30 Jun 2017

HAL is a multi-disciplinary open access archive for the deposit and dissemination of scientific research documents, whether they are published or not. The documents may come from teaching and research institutions in France or abroad, or from public or private research centers.
L'archive ouverte pluridisciplinaire HAL, est destinée au dépôt et à la diffusion de documents scientifiques de niveau recherche, publiés ou non, émanant des établissements d'enseignement et de recherche français ou étrangers, des laboratoires publics ou privés. 


\title{
Experimental investigation of a Doubly-Excited Flux-Switching Machine for Aircraft DC Power Generation
}

\author{
Andre Nasr ${ }^{1}$, Sami Hlioui ${ }^{2}$, Mohamed Gabsi ${ }^{1}$, Mathieu Mairie ${ }^{3}$, Didier Lalevee ${ }^{3}$ \\ ${ }^{1}$ SATIE, ENS Cachan, Université Paris-Sud, CNRS, Université Paris-Saclay, 94235 Cachan, France \\ ${ }^{2}$ SATIE, CNAM, ENS Cachan, CNRS, 292, Rue St Martin 75141 Paris Cedex, France \\ ${ }^{3}$ TAES, THALES avionics, 78400 Chatou, France
}

\begin{abstract}
This paper presents an experimental study on a new design of a Doubly-Excited Flux-Switching Machine (DEFSM) proposed for variable speed DC power generation in future aircraft. This machine uses excitation coils associated with permanent magnets to control the flux-linkage. This gives the possibility of using a diode bridge rectifier which is more reliable than an active bridge. After presenting its design and some of its main characteristics, an experimental investigation of the electromagnetic and thermal performances has been performed on a $3 \mathrm{~kW}$ prototype. It is shown that the generated power can be easily controlled using the excitation current which is very interesting for wide-speed-range applications. The unique design of the stator makes it possible to have a low remanent back EMF. This characteristic makes this machine inherently safe in case of fault since no flux weakening is needed. The thermal analysis has shown that the permanent magnets can be kept at relatively low temperatures which makes them more resistant to demagnetization. All of this makes the DEFSM a strong candidate for future aircraft power generation.
\end{abstract}

Index Terms-Aircraft power generation, DC alternator, Fluxswitching machine, Hybrid excitation, More electric aircraft

\section{INTRODUCTION}

The increase demand to improve aircraft performance has been a big challenge for the aviation industry in recent years. With over two million passengers traveling around the world every day, a lot of effort is being made to make the aircraft more secure and environmentally friendly. Reducing fuel consumption and gas emissions is always the prime objective but maintaining low operating and maintenance costs is essential in searching for new solutions. Many studies have been directed toward the concept of More Electric Aircraft (MEA) in search for more reliability and efficiency [1]. This new concept implies increasing use of electrical power to drive aircraft subsystems that have been conventionally driven by a combination of mechanical, hydraulic and pneumatic power [2].

The current generator technology employed on most commercial and military aircraft is the three-stage wound-field brushless synchronous generator [3] [4]. It includes a Permanent Magnet Generator (PMG), an exciter and a main machine (Fig. 1). The exciter has its AC windings installed on the rotor. These windings are connected to a rotating diode bridge rectifier in order to feed the field winding of the main machine without using slip rings and brushes. Most of the three-stage generators were initially driven by a hydro-mechanical Constant Speed Drive (CSD) that allows electrical power generation at a constant frequency of $400 \mathrm{~Hz}$ [5], however, new generation aircraft like Airbus A380 and Boeing B787 Dreamliner feature variable speed generators directly coupled to the engine shaft and generating variablefrequency electric power between 360 and $800 \mathrm{~Hz}$ [6]. This has significantly reduced weight and maintenance costs compared to previous fixed-frequency power systems using CSD. The main advantages of the three-stage brushless generator are high reliability and safety since it can be easily de-energized by simply cutting the excitation current. This current offers an efficient control of the excitation flux allowing wide-speed power regulation. However, the wound rotor technology with rotating diodes limits the machine speed hence the achievable power density. Moreover, this configuration doesn't allow motor mode usage which justifies the use of a high pressure bleed air system to start turbine engines [7].

Whatever the machine topology adopted in future aircraft, it should fulfill the new requirements of power generation systems especially the starter function, allowing the removal of the conventional air starter :

- No use of slip rings and brushes

- DC generation using a diode bridge rectifier

- Wide-speed-range operation

- Use of permanent magnets in order to allow selfexcitation

- Low remanent back EMF in case of fault

- Use of the generator as a starter

The most common electrical machines proposed in literature for this application are induction, switched reluctance and Permanent Magnet (PM) machines [8]. The advantages of an induction machine are well described in [9] and [10], however, it requires complex power electronics in generator mode and 


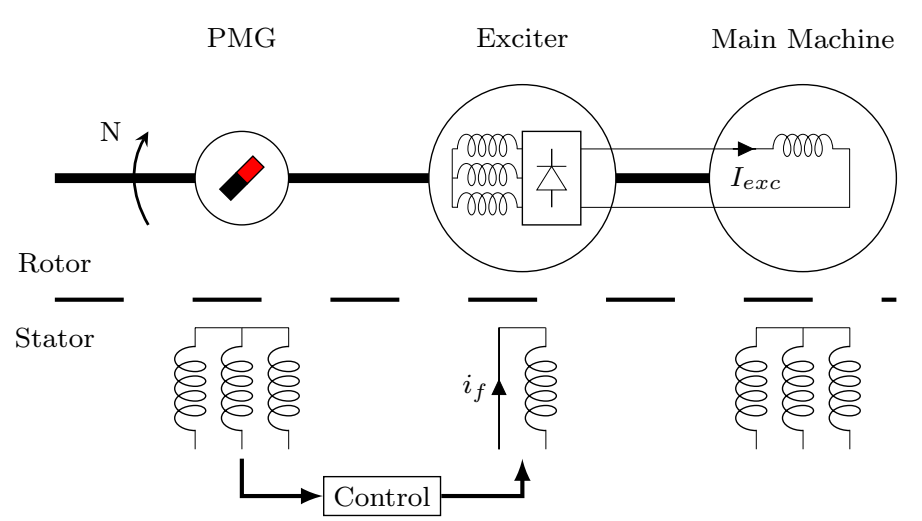

Fig. 1: Three-stage wound-field brushless synchronous generator

is considered unlikely to have the power density of its rivals [2]. The Switched Reluctance machine is characterized by an intrinsic high fault tolerance and high ruggedness due to its simple rotor construction [1], [11]. It has very good performances in motor mode but produces high torque ripples. In generator mode, current ripples can be reduced by using a filter capacitor, but like the induction machine, it doesn't allow self-excitation. The PM machine satisfies a large number of the criteria for a MEA generator, however, its intrinsic permanent flux cannot be controlled as with a wound field machine, which in this case implies the use of an active bridge rectifier for variable speed operations.

This paper presents a new design of a Doubly-Excited Flux-Switching Machine (DEFSM) for aircraft DC power generation. This design has the advantage of having a low remanent flux-linkage, a very important safety requirement in aircraft power generation. In the next section, we will present the design of the DEFSM and its main characteristics. Later on, a full experimental investigation will be performed on a $3 \mathrm{~kW}$ prototype and the electromagnetic and thermal performances will be discussed.

\section{DOUBLY-EXCITED FLUX-SWITCHING MACHINE DESIGN}

The three-phase doubly-excited flux-switching machine is a breakthrough in the world of hybrid machines [12]-[16]. The structure studied in this paper has a 10 poles salient rotor made of stacked silicon-iron ( $\mathrm{SiFe}$ ) sheets and a cobaltiron $(\mathrm{CoFe})$ stator composed of 12 elementary cells containing armature coils, permanent magnets and excitation coils (Fig. 2). Unlike the three-stage wound machine, the DEFSM has the advantage of using a passive rotor that allows it to operate at high rotational speeds. This helps achieve higher power densities especially with the use of permanent magnets. The DEFSM can also be used in motor mode allowing the removal of the air starter system. The positioning of the excitation coils in the stator avoids the use of undesirable slip rings and brushes. These coils give this machine a high capability of flux-regulation which is a very important characteristic for wide-speed-range DC power generation because it allows the use of the more reliable Diode Bridge Rectifier (DBR) [17].

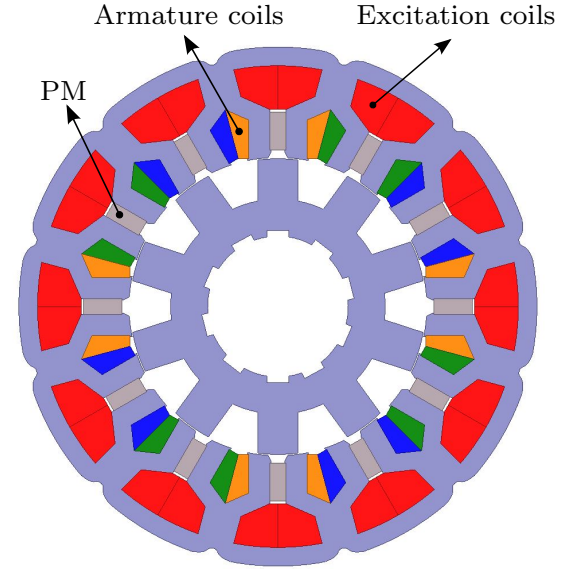

Fig. 2: Cross section of the DEFSM

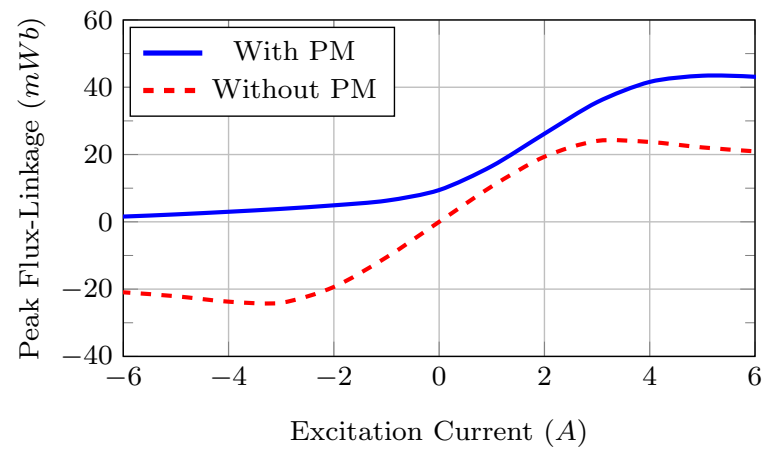

Fig. 3: Simulated no-load peak flux-linkage with and without PM

The singularity of the design presented in this paper can be seen in Fig. 3. This figure shows the no-load peak fluxlinkage versus the excitation current $\left(I_{e x c}\right)$ with and without permanent magnets. It can be clearly seen that the PMs allow to reach a higher flux-linkage. The ratio between the two maximum points is equal to 2 for this machine. The fluxregulation is very efficient too as we have a ratio of 5 between the flux values at 0 and $5 \mathrm{~A}$ (with PM). This is due to the presence of 12 excitation coils in the stator working in a parallel configuration with the permanent magnets. This configuration increases significantly flux control efficiency and reduces the risk of PM demagnetization. However, the most interesting characteristic of this design is at zero excitation current. We can see that the remanent flux-linkage $\left(\mathrm{I}_{\mathrm{exc}}=0 \mathrm{~A}\right)$ is only about $20 \%$ of the maximum flux reached $(9 \mathrm{mWb}$ to 44 $\mathrm{mWb}$ ). This ratio is considerably smaller than in conventional hybrid machines. In order to understand the reasons behind this low remanent flux-linkage, we present in Fig. 4 the flux lines and the flux density patterns in the DEFSM for Iexc $=0 \mathrm{~A}$. With no current in the excitation coils, the majority of the flux created by the permanent magnets completes its loop in the stator yoke through the magnetic bridge and only a small part $\left(\varphi_{0}\right)$ passes through the air-gap forming the remanent flux which can be used for self-excitation in case of dead batteries. 


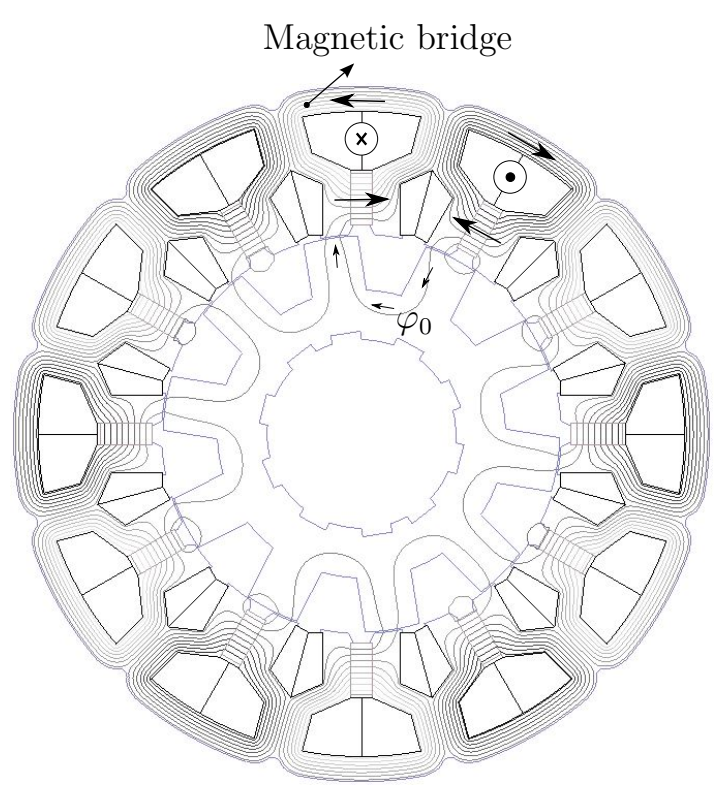

Fig. 4: No-load flux lines in the DEFSM for $\mathrm{I}_{\mathrm{exc}}=0 \mathrm{~A}$

Unlike permanent magnet or conventional hybrid machines, $\varphi_{0}$ is small enough to be considered as safe and therefore no flux weakening is needed in case of fault. However, by using a negative excitation current, it is possible to further reduce the flux-linkage as shown in Fig. 3.

We will present in the next section a $3 \mathrm{~kW}$ prototype on which we will perform various experimental measurements in order to understand the electromagnetic and thermal behaviors of the DEFSM under a wide range of speeds. Although this prototype is not optimized, it will allow us to investigate the main characteristics and advantages of the DEFSM in an aircraft power generation system.

\section{EXPerimental inVESTigation AND PeRformance ANALYSIS OF THE DEFSM}

Fig. 5 shows a photo of the experimental bench used to test the prototype with (1) the DEFSM, (2) an induction machine and (3) a diode bridge rectifier. This prototype has 28 turns per armature coil and 12 Samarium-Cobalt (SmCo) permanent magnets as shown in table I. SmCo magnets are often used in high temperature applications needing high magnetic performance. They have high temperature ratings (up to $250{ }^{\circ} \mathrm{C}$ ) and high coercivity which makes them extremely resistant to demagnetization. This prototype was designed to deliver its nominal power between 6000 and $12000 \mathrm{rpm}$. It has an external stator diameter of $140 \mathrm{~mm}$ with an air-gap of $0.35 \mathrm{~mm}$.

\section{A. No-load flux-linkage and short-circuit current}

Fig. 6 shows a capture of the back-EMF waveforms for $\mathrm{I}_{\mathrm{exc}}=0 \mathrm{~A}$ at $12000 \mathrm{rpm}$. At this speed, the voltage is about $80 \mathrm{Vrms}$ with a maximum of $380 \mathrm{Vrms}$ reached for $\mathrm{I}_{\mathrm{exc}}=5 \mathrm{~A}$ as shown in Fig. 7. This low remanent voltage leads to a low short-circuit current $I_{s c}$. At $\mathrm{I}_{\mathrm{exc}}=0 \mathrm{~A}, \mathrm{I}_{\mathrm{sc}}$ is limited

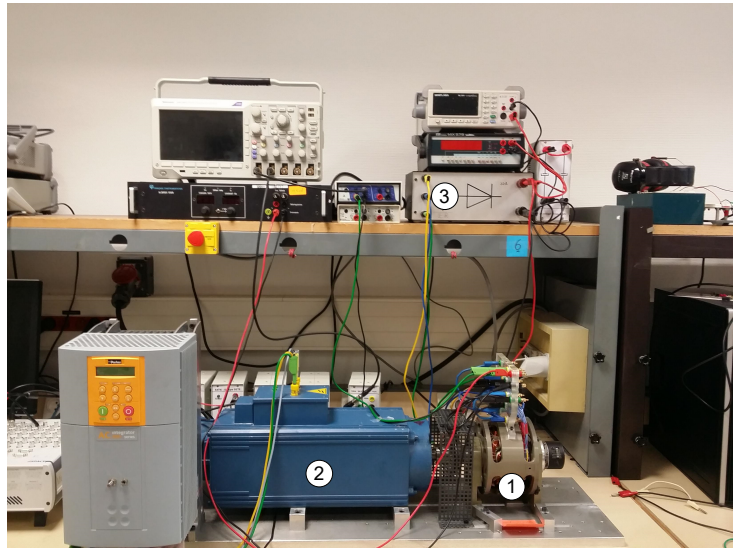

Fig. 5: Photo of the experimental bench

TABLE I: PROTOTYPE SPECIFICATIONS

\begin{tabular}{ll}
\hline \hline & \\
Number of stator elementary cells & 12 \\
Number of rotor teeth & 10 \\
Number of phases & 3 \\
Number of turns per armature coil & 28 \\
SmCo PM residual induction & $1.1 \mathrm{~T}\left(20^{\circ} \mathrm{C}\right)$ \\
External stator diameter & $140 \mathrm{~mm}$ \\
Air-gap & $0.35 \mathrm{~mm}$ \\
Nominal power & $3 \mathrm{~kW}$ \\
& \\
\hline
\end{tabular}

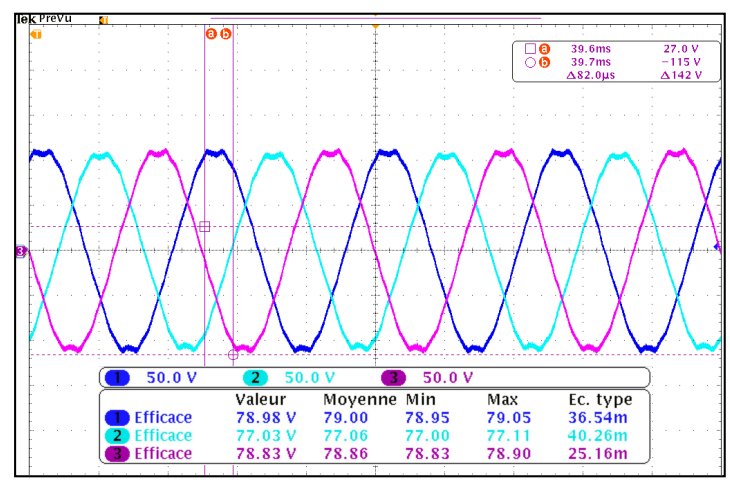

Fig. 6: Captured no-load back EMF waveforms for $\mathrm{I}_{\mathrm{exc}}=0 \mathrm{~A}$ at $12000 \mathrm{rpm}$ (Horizontal : $200 \mu \mathrm{s} /$ div, Vertical : $50 \mathrm{~V} /$ div)

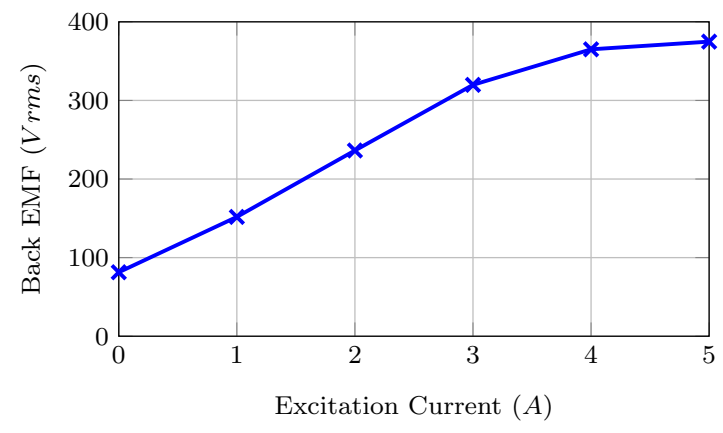

Fig. 7: Measured back EMF at $12000 \mathrm{rpm}$ 


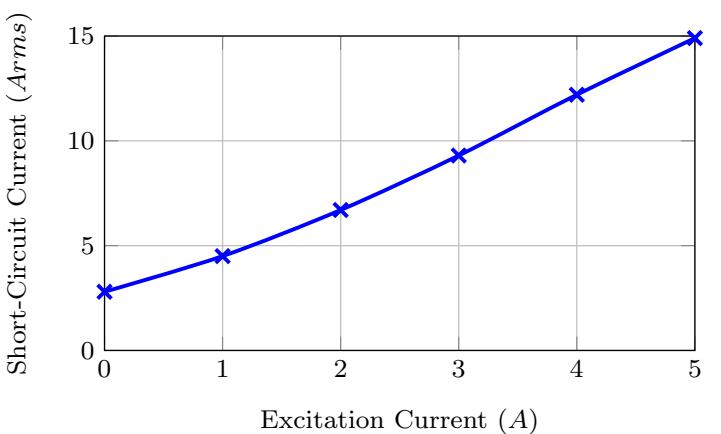

Fig. 8: Measured short-circuit current $\left(I_{s c}\right)$ at $12000 \mathrm{rpm}$

to 3 Arms (Fig. 8) which corresponds to a current density of $4 \mathrm{Arms} / \mathrm{mm}^{2}$ for this prototype. This characteristic is very important in critical applications like aircraft power generation. By simply cutting the excitation current, the back EMF and the short-circuit current will be limited to very low values and therefore there will be no risk of damaging the machine in case of fault.

\section{B. DC power generation using a diode bridge rectifier}

As mentioned above, the DEFSM will be used as a DC generator [18], [19]. It will be connected to a diode bridge rectifier feeding a constant $270 \mathrm{~V}$ DC bus as shown in Fig. 9. The use of DBR is favored in future aircraft in an attempt to find maximum reliability. The induction motor powered by a three-phase inverter was employed as a prime mover. This inverter is mainly fed by the generated power and by the grid to cover the losses of the overall system. The various measurements collected are listed below :

- $\mathrm{P}_{\text {mech }}$ : The mechanical power on the drive shaft

- $\mathrm{I}_{\mathrm{ph}}$ : The phase current

- $\mathrm{i}_{\text {DC }}$ : The DC current at the DBR output

- $\mathrm{T}_{\mathrm{exc}}, \mathrm{T}_{\mathrm{arm}}, \mathrm{T}_{\mathrm{pm}}$ : Temperature measurements of the excitation coils, the armature coils and the permanent magnets

$P_{\text {mech }}$ is determined by measuring the torque on the drive shaft and multiplying it by the angular velocity. Fig. 10 and 11 show respectively the phase current and the rectified DC current for $\mathrm{I}_{\mathrm{exc}}=4 \mathrm{~A}$ at $12000 \mathrm{rpm}$. The mean value $i_{D C}$ is equal to $12.3 \mathrm{~A}$ at this operating point. The $\mathrm{DC}$ output power is determined as follows :

$$
P_{\text {output }}=U_{D C} i_{D C}
$$

with $U_{D C}$ the DC bus voltage. In order to determine the core losses of the machine, armature copper losses must be calculated first :

$$
P_{\text {arm }}=3 R_{p h} I_{r m s}^{2}
$$

$R_{p h}$ is a $0.5 \Omega$ phase resistance calculated at $100{ }^{\circ} \mathrm{C}$ and $I_{r m s}$ the rms value of the phase current. Considering that the

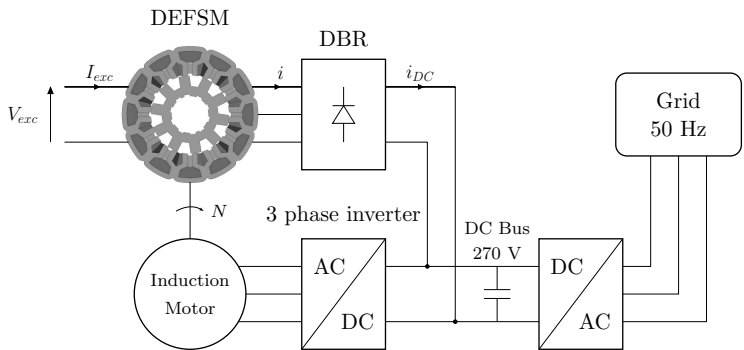

Fig. 9: Scheme of the experimental setup

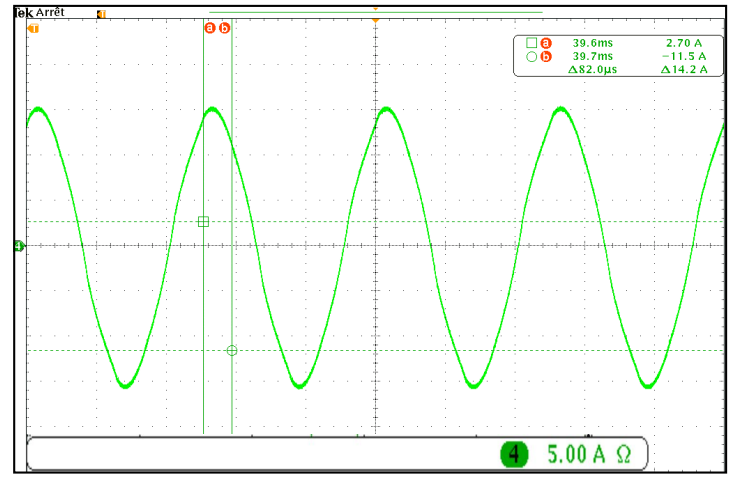

Fig. 10: Measured phase current for $\mathrm{I}_{\mathrm{exc}}=4 \mathrm{~A}$ at $12000 \mathrm{rpm}$ (Horizontal : $200 \mu \mathrm{s} /$ div, Vertical : 5 A / div)

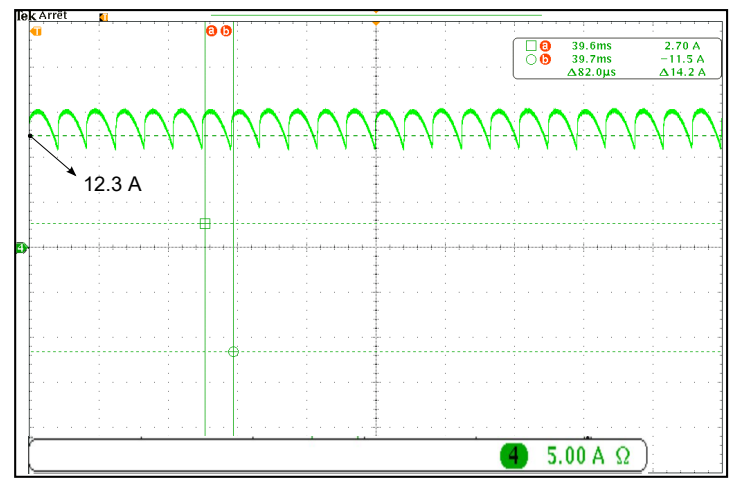

Fig. 11: Measured DC current for $\mathrm{I}_{\mathrm{exc}}=4 \mathrm{~A}$ at $12000 \mathrm{rpm}$ (Horizontal : $200 \mu \mathrm{s} /$ div, Vertical : 5 A / div)

mechanical losses (friction and windage) are negligible, the core losses can be determined using (3) :

$$
P_{\text {coreloss }}=P_{\text {mech }}-P_{\text {output }}-P_{\text {arm }}
$$

Fig. 12 and 13 show some measurements performed on the test bench at 6000 and $12000 \mathrm{rpm}$. We can notice that the copper losses in the armature windings are much lower than in the excitation coils. At 12000 rpm (Fig. 13(a)), these losses are about $250 \mathrm{~W}$ for $\mathrm{I}_{\mathrm{exc}}=6 \mathrm{~A}$ compared to $1000 \mathrm{~W}$ in the excitation winding. At $6000 \mathrm{rpm}$, the core losses are comparable to the copper losses in the excitation. They vary between 200 and $800 \mathrm{~W}$. However, by increasing the rotational speed, the core losses increase rapidly and at $12000 \mathrm{rpm}$ they are equal to $1100 \mathrm{~W}\left(\mathrm{I}_{\mathrm{exc}}=6 \mathrm{~A}\right)$. 


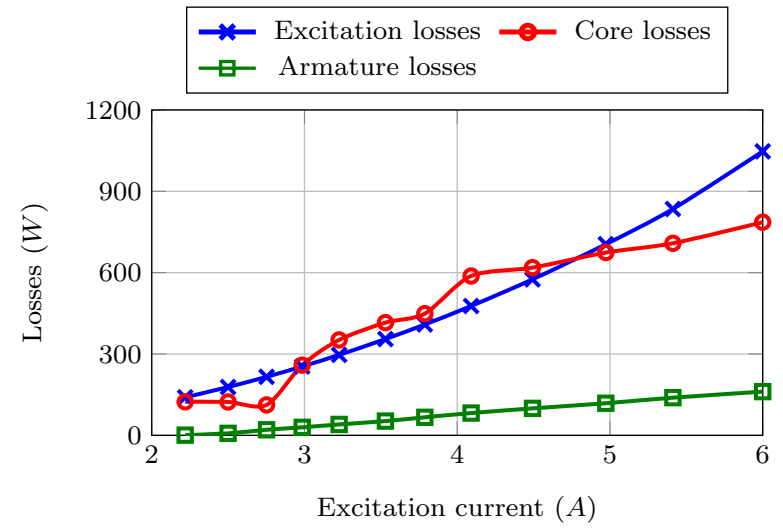

(a) Copper and core losses

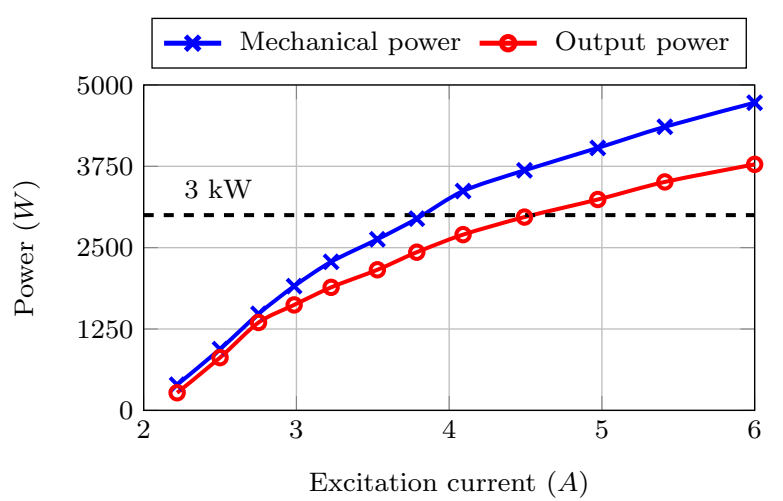

(b) Mechanical power and output power

Fig. 12: Various measurements performed on the DEFSM at $6000 \mathrm{rpm}$

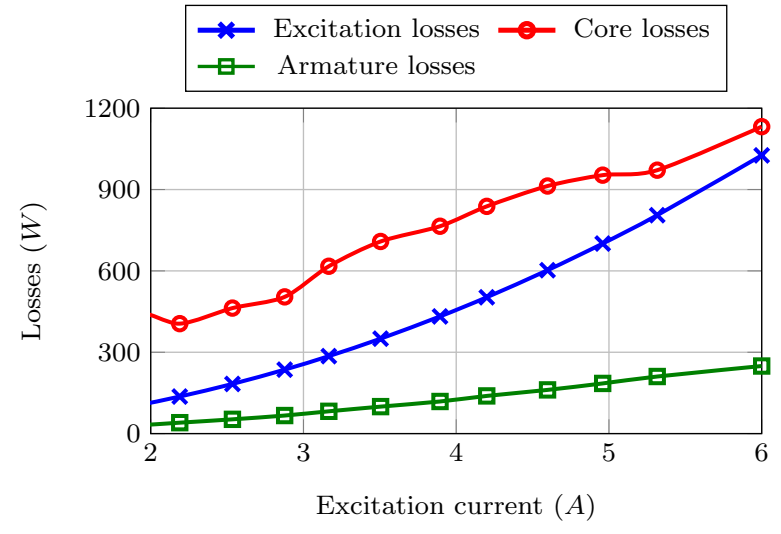

(a) Copper and core losses

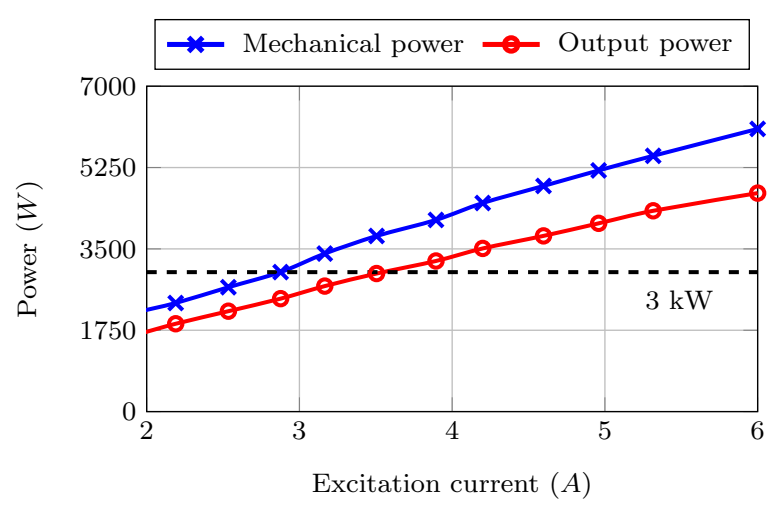

(b) Mechanical power and output power

Fig. 13: Various measurements performed on the DEFSM at $12000 \mathrm{rpm}$

The evolution of the output power is shown in Fig. 12(b) and 13(b) at 6000 and $12000 \mathrm{rpm}$ as a function of the excitation current. For $\mathrm{I}_{\mathrm{exc}}=6 \mathrm{~A}$, the power is about 3800 $\mathrm{W}$ at $6000 \mathrm{rpm}$ while at $12000 \mathrm{rpm}$ it is equal to 4700 W. Theses figures highlight the good capability of power regulation of the DEFSM. By increasing $I_{e x c}$ from 3 to 5 A (+ $66 \%$ ), the power at $6000 \mathrm{rpm}$ goes from 1600 to $3300 \mathrm{~W}$ (+ $100 \%$ ). This characteristic is very important in wide-speedrange applications as the power can be kept constant despite sudden speed variations of aircraft engines. Fig. 14 shows the evolution of the excitation and core losses for a constant output power of $3 \mathrm{~kW}$ versus the rotational speed between 6000 and $12000 \mathrm{rpm}$. As the speed increases, a smaller excitation current is needed to maintain a constant power. As Fig. 12(b) and 13(b) show, $I_{e x c}$ is equal to $4.5 \mathrm{~A}$ at $6000 \mathrm{rpm}$ and drops to $3.5 \mathrm{~A}$ at $12000 \mathrm{rpm}$. The excitation copper losses drop therefore from 600 to $350 \mathrm{~W}$. With a decreasing excitation current, the flux densities in the machine are smaller. This leads to a decrease of core losses until $8000 \mathrm{rpm}$ where they start to increase again. This can be explained by the fact that between 6000 and $8000 \mathrm{rpm}(+33 \%), I_{e x c}$ decreases from

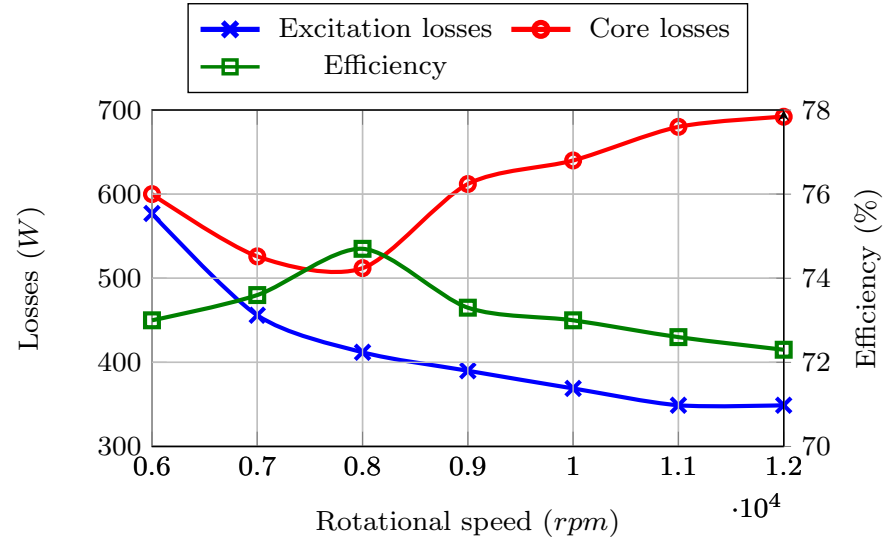

Fig. 14: Excitation losses, core losses and efficiency versus the rotational speed for a constant output power of $3 \mathrm{~kW}$

4.5 to $3.8 \mathrm{~A}(-15 \%)$ while from 8000 to $12000 \mathrm{rpm}(+50 \%)$, the excitation current decreases by only $8 \%$ (3.8 to $3.5 \mathrm{~A})$. Since the core losses are dependent on both the flux density and the frequency, the slow decreasing current in this latter 


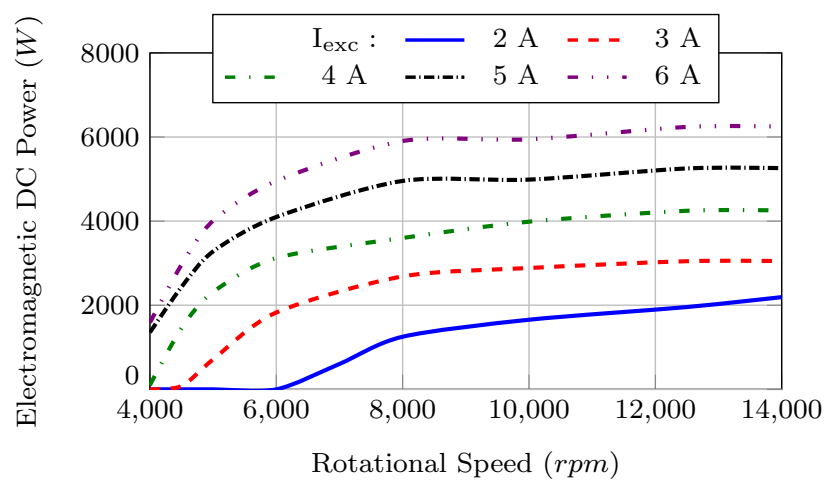

Fig. 15: Simulated electromagnetic power versus speed

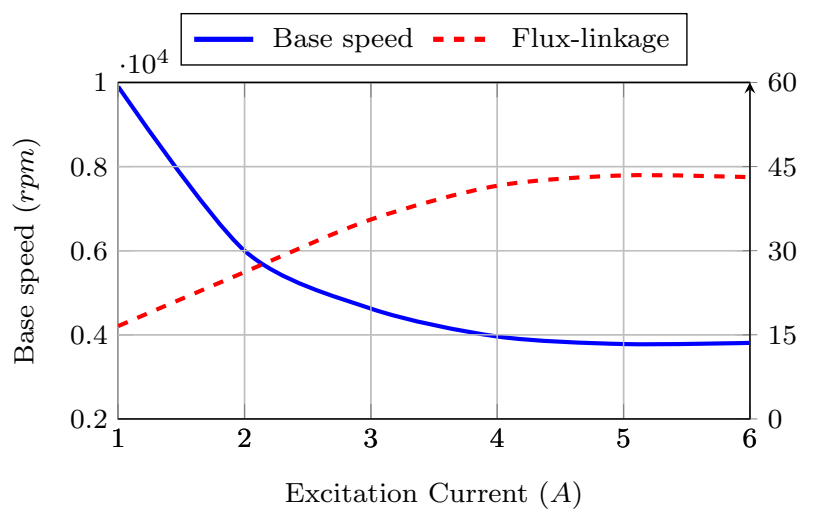

Fig. 16: Base speed versus $I_{\text {exc }}$ for $U_{D C}=270 \mathrm{~V}$

speed range is not enough to overcome the increasing speed, and therefore the core losses get higher. As for the efficiency, it remains almost constant with $72 \%$ at $12000 \mathrm{rpm}$.

Fig. 15 shows the simulated electromagnetic power versus the rotational speed for several excitation currents. We can notice that for $\mathrm{I}_{\mathrm{exc}}=2 \mathrm{~A}$, the power is zero for a rotational speed smaller than $6000 \mathrm{rpm}$, and that by increasing $I_{\text {exc }}$ we allow power generation at lower speeds. In fact, the DC electromagnetic power can also be written as [20] :

$$
P_{\text {electmag }}=3 V I_{c c} \sqrt{1-\left(\frac{N_{b}}{N}\right)^{2}}
$$

with $V$ the phase voltage rms value, $I_{c c}$ the short-circuit current and $N$ the rotational speed. $N_{b}$ is a base speed that depends on the no-load flux-linkage $\varphi_{M}$ and on the DC bus voltage as shown in (5) :

$$
N_{b}=\frac{60}{\pi^{2}} \frac{1}{p} \frac{1}{\varphi_{M}\left(I_{e x c}\right)} U_{D C}
$$

with $p$ the number of rotor poles equal to 10 in our case. Fig. 16 shows the evolution of $N_{b}$ versus the excitation current for $\mathrm{U}_{\mathrm{DC}}=270 \mathrm{~V}$. For $\mathrm{I}_{\mathrm{exc}}=1 \mathrm{~A}$, no power transfer can occur through the DBR unless $N$ is bigger than $10000 \mathrm{rpm}$. By increasing $I_{e x c}, \varphi_{M}$ increases too which leads to a smaller base speed. For $\mathrm{I}_{\mathrm{exc}}=6 \mathrm{~A}, N_{b}$ is equal to $3800 \mathrm{rpm}$.

\section{Thermal behavior of the DEFSM}

In order to have a full investigation of the DEFSM, thermal behavior must be given the same attention as electromagnetic behavior. Platinum resistance thermometers (PT 1000) were installed on the prototype and temperature measurements were collected for several operation points (Fig. 17). An air ventilation system providing an airflow of $60 \mathrm{~g} / \mathrm{s}$ has been used to cool down the machine. Fig. 18 shows the temperature evolution of an excitation coil as a function of the output power at 6000 and $12000 \mathrm{rpm}$. It is clearly seen that the temperature is higher at $6000 \mathrm{rpm}$. For an output power of $3800 \mathrm{~W}$, the temperature rises up to $170{ }^{\circ} \mathrm{C}$. This can be explained by the fact that for the same output power, a higher excitation current is needed at a lower speed which increases the copper losses in the excitation winding and therefore its temperature. In the armature windings, copper losses are the same for a constant output power whatever is the rotational speed. But, due to the small distance separating the excitation and the armature slots, armature windings become hotter at $6000 \mathrm{rpm}$ as shown in Fig. 19. However, due to lower copper losses, the temperature of the armature windings are much lower than the excitation winding with a maximum of $100{ }^{\circ} \mathrm{C}$. Finally, we can notice that the permanent magnets are somehow protected from the heat sources since they reach a maximum temperature of only $70{ }^{\circ} \mathrm{C}$ (Fig. 20). This can be a great advantage for the DEFSM as it will be possible to use other types of permanent magnets that have lower temperature ratings like the Neodymium Iron

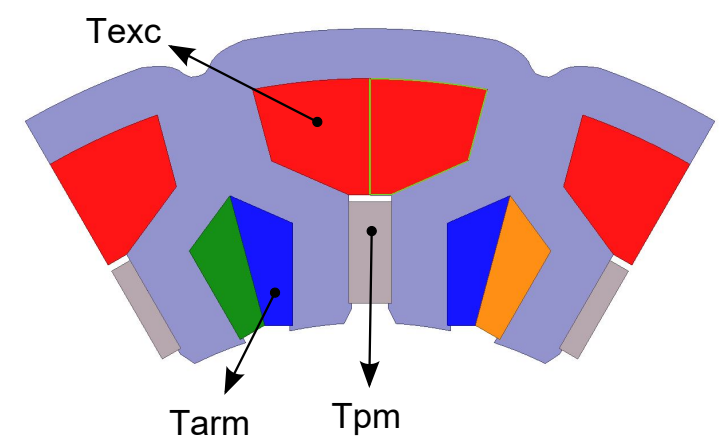

Fig. 17: Thermometers installed on the DEFSM

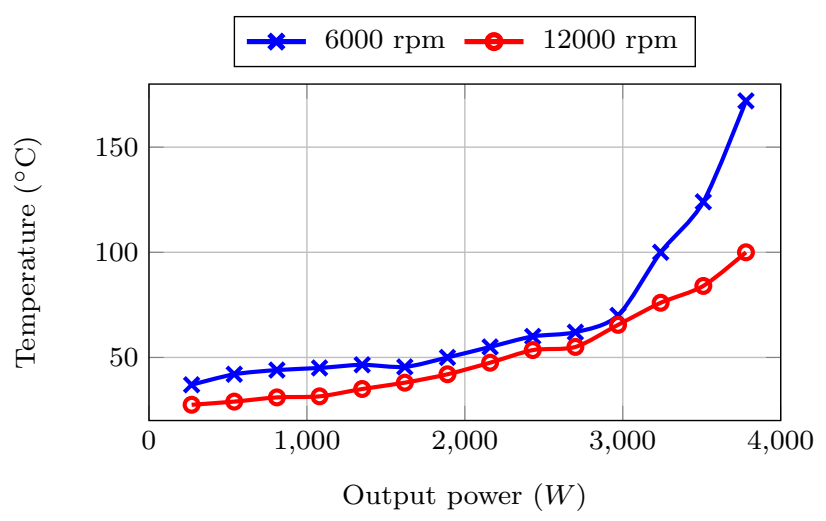

Fig. 18: Excitation coil temperature $T_{\text {exc }}$ versus output power 


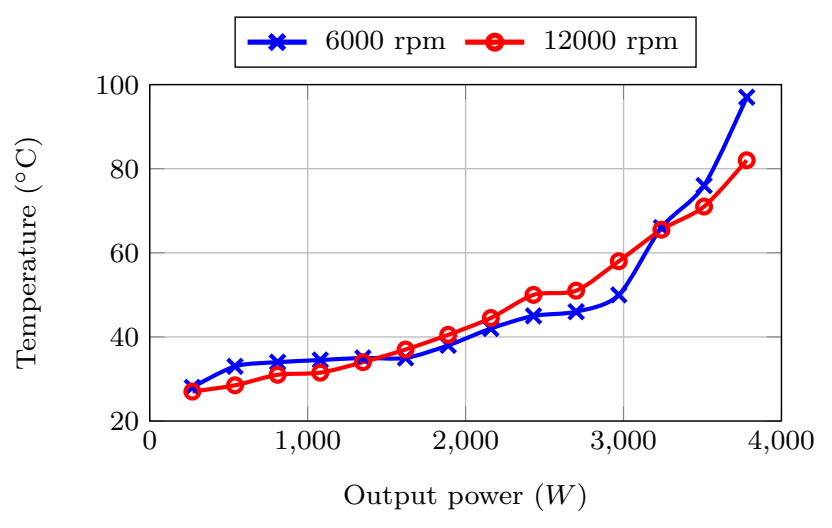

Fig. 19: Armature coil temperature $\mathrm{T}_{\mathrm{arm}}$ versus output power

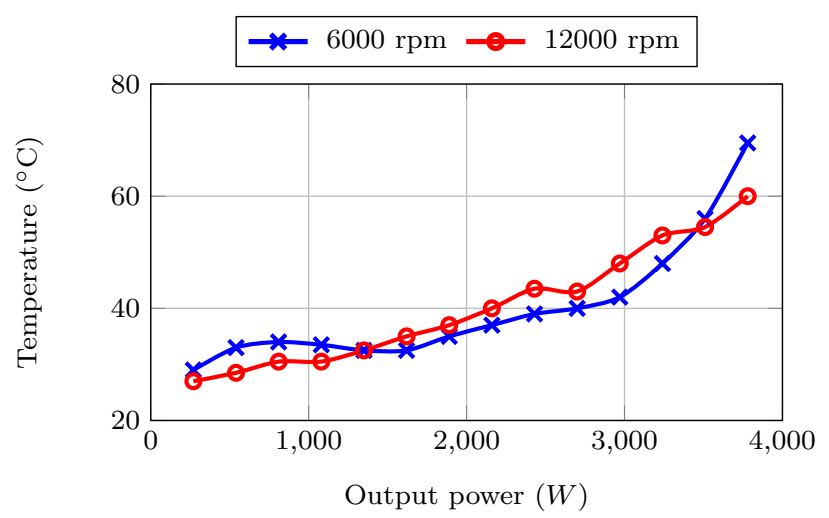

Fig. 20: Permanent magnet temperature $T_{\mathrm{pm}}$ versus output power

Boron $(\mathrm{NdFeB})$. This type of permanent magnets is generally cheaper than the Cobalt-iron, mechanically stronger and has higher performances.

\section{CONCLUSION}

This paper has presented an experimental study on a new design of a doubly-excited flux-switching machine for aircraft DC power generation. Unlike conventional hybrid machines, the DEFSM can have very low remanent back EMF due to its special stator design. This makes it inherently safe for aircraft power generation as no flux weakening is needed in case of fault. The DEFSM has a passive and robust rotor which makes it suitable for high speed applications. All heat sources are positioned in the stator which makes thermal management an easier task. However, it has been shown that a simple air ventilation system is sufficient to keep the permanent magnets at low temperatures. The excitation coils give this machine a high capability of power regulation which is a very important characteristic for wide-speed-range DC power generation as it allows using the more reliable diode bridge rectifier. All these characteristics make the DEFSM a strong candidate to replace the three-stage generator in future more electric aircraft.

\section{REFERENCES}

[1] J. A. Rosero, J. A. Ortega, E. Aldabas, and L. Romeral, "Moving towards a more electric aircraft," IEEE Aerospace and Electronic Systems Magazine, vol. 1, pp. 143 - 147, March 2007.

[2] A. A. Abdelhafez and A. J. Forsyth, "A review of more-electric aircraft," 13th international conference on Aerospace Science and Aviation Technology conference, 26 - 28 May 2009.

[3] G. M. Raimondi, T. Sawata, M. Holme, A. Barton, G. White, J. Coles, P. H. Mellor, and N. Sidell, "Aircraft embedded generation systems," IEEE International Conference on Power Electronics, Machines and Drivesl, pp. 217 - 222, 4 - 7 June 2002.

[4] C. R. Avery, S. G. Burrow, and P. H. Mellor, "Electrical generation and distribution for the more electric aircraft," International Universities Power Engineering Conference, pp. 1007 - 1012, 4 - 7 Sept 2007.

[5] A. Emadi and M. Ehsani, "Aircraft power systems : technology, state of the art, and future trends," IEEE Aerospace and Electronic Systems Magazine, vol. 15, pp. 28 - 32, Aug 2000.

[6] Z. Xin, J. M. Guerrero, and W. Xiaohua, "Review of aircraft electric power systems and architectures," IEEE International Energy Conference (ENERGYCON), pp. 949-953, 13 - 16 May 2014.

[7] R. T. Naayagi, "A review of more electric aircraft technology," International Conference on Energy Efficient Technologies for Sustainability (ICEETS), pp. 750 - 753, 10 - 12 April 2013.

[8] R. Krishnan and A. S. Bharadwaj, "A comparative study of various motor drive systems for aircraft application," IEEE Industry Applications Society Annual Meeting, pp. 252 - 258, Sept 28 - Oct 41991.

[9] T. Feehally and J. Apsley, "The doubly-fed induction machine as an aero generator," IEEE Transactions on Industry Applications, vol. 51, pp. 3462 - 3471, March 2015.

[10] R. C. Bansal, "Three-phase self-excited induction generators : An overview," IEEE Transactions on Energy Conversion, vol. 20, pp. 292 - 299, June 2005.

[11] T. L. Skvarenina, O. Wasynczuk, P. C. Krause, W. Z. Chen, R. J. Thibodeaux, and J. Weimer, "Simulation and analysis of a switched reluctance generator/more electric aircraft power system," IEEE Energy Conversion Engineering Conference, pp. 143 - 147, 11 - 16 Aug 1996.

[12] E. Hoang, M. Lecrivain, and M. Gabsi, "A new structure of a switching flux sunchronous polyphased machine with hybrid excitation," European Conference on Power Electronics and Applications, 2 - 7 Sept 2007.

[13] E. Hoang, M. Lecrivain, and M. Gabsi, "Flux-switching dual excitation electrical machine," Patent Us 7868506 B2, Jan 11, 2011.

[14] B. Gaussens, E. Hoang, M. Lcrivain, P. Manfe, and M. Gabsi, "A hybrid-excited flux-switching machine for high-speed dc-alternator applications," IEEE Transactions on Industrial Electronics, vol. 61, no. 6, pp. 2976-2989, June 2014.

[15] G. J. Li, Z. Q. Zhu, and G. Jewell, "Performance investigation of hybrid excited switched flux permanent magnet machines using frozen permeability method," IET Electric Power Applications, vol. 9, no. 9, pp. 586-594, 2015.

[16] E. Sulaiman and T. Kosaka, "Development of high torque and high power density hybrid excitation flux switching motor for traction drive in hybrid electric vehicles," Energy and Power Engineering, vol. 5, no. 7, pp. 446 - 454, September 2013.

[17] Y. Wang and Z.-Q. Deng, "Analysis of electromagnetic performance and control schemes of electrical excitation flux-switching machine for dc power systems," IEEE Transactions on Energy Conversion, vol. 27, pp. 844 - 855, Sept 2012.

[18] Y. Amara, M. Gabsi, L. Vido, H. Ben Ahmed, E. Hoang, M. Lécrivain, and A. Takorabet, "Classification of alternators connected to diode rectifiers with constant voltage loads. maximum output-current characteristics," European Journal of Electrical Engineering, vol. 13, no. 1, pp. 33-89, 2010.

[19] I. Jadric, D. Borojevic, and M. Jadric, "A simplified model of a variable speed synchronous generator loaded with diode rectifier," IEEE Power Electronics Specialists Conference, pp. 497 - 502, 22 - 27 Jun 1997.

[20] A. Dupas, S. Hlioui, E. Hoang, M. Gabsi, and M. Lecrivain, "Investigation of a new topology of hybrid-excited flux-switching machine with static global winding: Experiments and modeling," IEEE Transactions on Industry Applications, vol. 52, no. 2, pp. 1413-1421, March 2016. 